\title{
Polyphasic analysis of Acidovorax citrulli strains from northeastern Brazil
}

\author{
Kirley Michele Marques Silva ${ }^{1}$, André Silva Xavier ${ }^{1}$, Marco Aurélio Siqueira Gama ${ }^{1}$,Nelson Bernardi Lima ${ }^{1}$, Maria do Carmo \\ Castanho Pereira Lyra ${ }^{3}$, Rosa Lima Ramos Marianoํㅡ, Elineide Barbosa Souza2*
}

${ }^{1}$ Federal Rural University of Pernambuco - Dept. of Agronomy, Av. Dom Manoel de Medeiros, s/n - 52171-900

- Recife, PE - Brazil.

${ }^{2}$ Federal Rural University of Pernambuco - Dept. of Biology. ${ }^{3}$ Agronomic Institute of Pernambuco, Av. General San Martin, 1371 - 50761-000 - Recife, PE - Brazil.

*Corresponding author <elineidebs@yahoo.com.br>

Edited by: Luís Eduardo Aranha Camargo

Received March 07, 2015

Accepted September 20, 2015

\begin{abstract}
Bacterial fruit blotch (BFB) of cucurbit plants is caused by Acidovorax citrulli and represents a serious concern to melon (Cucumis melo L.) growers worldwide, including those in Brazil. Thirty-four A. citrulli strains from different melon production areas of northeastern Brazil were characterized for their virulence on melon fruits and their substrate utilization and molecular profiles. Based on the analysis of BFB severity on melon fruits, the A. citrulli strains were divided into three groups, classified as mildly, moderately or highly virulent. Although host-related groups were not observed, the watermelon and 'melão-pepino' strains exhibited only low or moderate virulence on melon fruit. Substrate utilization profiles revealed that $94 \%$ of the 95 tested compounds were used by A. citrulli strains as a carbon source. Overall, based on substrate utilization, low variability was observed with no relationship to host of origin. The formation of one group of A. citrulli strains based on Repetitive Sequence-based PCR (rep-PCR) analysis confirmed the low variability observed in the substrate utilization analyses. Bayesian inference based on the analysis of $23 \mathrm{~S}$ rDNA partial sequence data resulted in one well-supported clade and clustered the strains with the $A$. citrulli-type species with high posterior probability support. Based on the markers used, the Brazilian A. citrulli strains belong to a single group, which corresponds to the previously described Group I for this bacterium in the United States.

Keywords: Cucumis melo, bacterial fruit blotch, variability
\end{abstract}

\section{Introduction}

Bacterial fruit blotch (BFB), caused by Acidovorax citrulli (Schaad et al.). Schaad et al. is a serious problem in melon- (Cucumis melo L.) and watermelon(Citrullus lanatus (Thunb.) Matsum. and Nakai) producing regions throughout the world (Burdman and Walcott, 2012). In Brazil, the most significant economic impact of BFB is on melon crops (Carvalho et al., 2013), mainly in the northeastern region, where yield losses are estimated at 40-50\%, but might reach 100 $\%$ (EPPO, 2010).

Initially, $A$. citrulli strains were thought to comprise a homogeneous population; however, it was subsequently shown that there was genetic variability (Burdman and Walcott, 2012). At first, it was observed that the ATCC29625 type strain (obtained from watermelon) did not cause a hypersensitive response (HR) in tobacco and had little virulence on watermelon compared with other strains isolated from the same host (Schaad et al., 1978; Somodi et al., 1991). Furthermore, strains causing BFB epidemics in cantaloupe melon in Queensland, Australia were considerably more virulent on melon and less virulent on the invading plant Cucumis myriocarpus Naudin compared with strains obtained from watermelon in the same state (O`Brien and Martin, 1999). This diversity was confirmed by Walcott et al. $(2000,2004)$ and two groups were defined: Group I represented strains from a wide range of cucurbitaceous species, including the ATCC29625 type strain, and were moderately virulent toward cantaloupe melon, pumpkin and zucchini. Group II represented strains responsible for epidemics in watermelons in the USA; these strains were more vir- ulent toward watermelon compared with other cucurbit plants (Walcott et al., 2004). These two groups were also reported in Israel by Burdman et al. (2005).

In Australia and the United States, $A$. citrulli strains obtained from various locations showed differences in substrate utilization profiles, which were correlated with host pathogenicity (O`Brien and Martin, 1999; Walcott et al., 2004). In Brazil, differences in virulence were also observed in $41 \mathrm{~A}$. citrulli strains tested on melon and watermelon seedlings, plants and fruits (Oliveira et al., 2007). Moreover, 22 strains from melon and watermelon were compared by biochemical, pathogenicity, serological and molecular assays, and only cross inoculation showed different pathogenicity groups (Melo et al., 2014). Considering the scarcity of studies on the genetic diversity of Brazilian $A$. citrulli strains isolated from melon and watermelon, this study aimed to contribute to a better understanding of the variability of $A$. citrulli strains based on virulence, substrate utilization profiles and sequences analysis.

\section{Materials and Methods}

\section{Acidovorax citrulli strains}

We studied $34 \mathrm{~A}$. citrulli strains from the Culture Collection of the Phytobacteriology Laboratory of the Federal Rural University of Pernambuco, Recife - Brazil, obtained from different production areas of northeastern Brazil, and six strains from the Phytobacteria Culture Collection of the Biological Institute, São Paulo - Brazil, including the IBSBF1851 type strain = ATCC29625 Group I sensu Walcott et al. (2004), which belongs to group I (Walcott et al., 2000) (Table 1). Of 
Table 1 - Designation, origin and virulence of 40 Brazilian Acidovorax citrulli strains used in this study.

\begin{tabular}{|c|c|c|c|c|}
\hline \multirow{3}{*}{$\begin{array}{l}\text { Strains }^{1} \\
\text { Aac1.12 } \\
\text { (AAC201-23) } \\
\text { Aac1.31 }\end{array}$} & Host $^{2}$ & Origin (City/State) & Severity (Score) ${ }^{3}$ & Virulence level $^{4}$ \\
\hline & Melon Yellow & Baraúna/RN & $6.0(0) a^{5}$ & +++ \\
\hline & Melon Yellow & Baraúna/RN & $6.0(0) \mathrm{a}$ & +++ \\
\hline Aac1.37 & Melon Yellow & Baraúna/RN & $6.0(0) \mathrm{a}$ & +++ \\
\hline Aac1.39 & Melon Yellow & Baraúna/RN & $6.0(0) \mathrm{a}$ & +++ \\
\hline Aac1.49 & Melon Yellow & Baraúna/RN & $6.0(0) \mathrm{a}$ & +++ \\
\hline \multirow{3}{*}{$\begin{array}{l}\text { Aac1.50 } \\
\text { Aac1.5 } \\
\text { (AAC201-22) } \\
\text { Aac1.78 }\end{array}$} & Melon Yellow & Baraúna/RN & $6.0(0) \mathrm{a}$ & +++ \\
\hline & Melon Yellow & Baraúna/RN & $6.0(0)$ a & +++ \\
\hline & Melon Yellow & Baraúna/RN & $6.0(0) \mathrm{a}$ & +++ \\
\hline Aac1.84 & Melon Yellow & Baraúna/RN & $6.0(0) \mathrm{a}$ & +++ \\
\hline Aac5.1 & Melon Frog skin & Baraúna/RN & $6.0(0) \mathrm{a}$ & +++ \\
\hline Aac5.20 & Melon Frog skin & Baraúna/RN & $6.0(0)$ a & +++ \\
\hline Aac8 & Melon Yellow & -6 & $6.0(0) \mathrm{a}$ & +++ \\
\hline Aac9 & Melon Yellow & - & $6.0(0) a$ & +++ \\
\hline Aac14 & Melon Yellow & - & $6.0(0) \mathrm{a}$ & +++ \\
\hline IBSBF1521 & Melon Yellow & Baraúna/RN & $6.0(0) \mathrm{a}$ & +++ \\
\hline Aac1.40 & Melon Yellow & Baraúna/RN & $5.2(1.5)$ a & +++ \\
\hline Aac5.16 & Melon Frog skin & Baraúna/RN & $5.2(1.5)$ a & +++ \\
\hline Aac1.73 & Melon Yellow & Baraúna/RN & $5.0(1.1)$ a & +++ \\
\hline Aac1.83 & Melon Yellow & Baraúna/RN & $5.0(2.0)$ a & +++ \\
\hline Aac1.45 & Melon Yellow & Baraúna/RN & $4.2(2.4) b$ & ++ \\
\hline Aac12 & Melon Yellow & - & $4.0(1.8) b$ & ++ \\
\hline Aac1.70 & Melon Yellow & Baraúna/RN & $4.0(2.3) b$ & ++ \\
\hline Aac1.72 & Melon Yellow & Baraúna/RN & $4.0(2.3) b$ & ++ \\
\hline Aac1.43 & Melon Yellow & Baraúna/RN & $4.0(2.2) b$ & ++ \\
\hline IBSBF1225 & Melon Yellow & Assú/RN & $3.8(2.6) b$ & ++ \\
\hline AacAR & Melon Yellow & Juazeiro/BA & $3.8(1.5) b$ & ++ \\
\hline AacMP2 & “Melão-pepino" & Baraúna/RN & $3.8(2.6) b$ & ++ \\
\hline IBSBF1627 & Watermelon & Brazil & $3.2(2.0) b$ & ++ \\
\hline AacR3 & Melon Yellow & Baraúna/RN & $3.0(0) b$ & ++ \\
\hline Aac5.28 & Melon Frog skin & Baraúna/RN & $3.0(0) b$ & ++ \\
\hline Aac1 (AAC201-21) & Melon Yellow & Baraúna/RN & $2.8(2.3) \mathrm{c}$ & + \\
\hline Aac180 & Watermelon & Petrolina/PE & $2.2(2.5) \mathrm{c}$ & + \\
\hline IBSBF1214 & Watermelon & Presidente Prudente/SP & $2.2(0.5) c$ & + \\
\hline \multirow{3}{*}{$\begin{array}{l}\text { IBSBF1213 } \\
\text { IBSBF1851 } \\
\text { (ATCC29625) } \\
\text { Aac1.35 }\end{array}$} & Watermelon & Presidente Prudente/SP & $2.0(0) c$ & + \\
\hline & Watermelon & United States & $2.0(0) \mathrm{c}$ & + \\
\hline & Melon Yellow & Baraúna/RN & $2.0(0) c$ & + \\
\hline \multirow{3}{*}{$\begin{array}{l}\text { Aac5.3 } \\
\text { AacR2 } \\
\text { (AAC201-24) } \\
\text { AacMP1 }\end{array}$} & Melon Frog skin & Baraúna/RN & $2.0(0) \mathrm{c}$ & + \\
\hline & Melon Charentais & Baraúna/RN & $2.0(0) \mathrm{c}$ & + \\
\hline & “Melão-pepino” & Mossoró/RN & $2.0(1.1) \mathrm{c}$ & + \\
\hline AacR7 & Melon Yellow & Baraúna/RN & $1.8(0.9) \mathrm{c}$ & + \\
\hline
\end{tabular}

${ }^{1}$ Type strain in bold; Aac- Culture Collection of the Phytobacteriology Laboratory of the Federal Rural University of Pernambuco, Recife, Brazil; AAC- melon strains renamed and classified as part of Group I (Walcott et al., 2004); IBSBF- Phytobacteria Culture Collection of the Biological Institute, São Paulo, Brazil; ATCC- American Type Culture Collection, Rockville, Maryland, USA; ${ }^{2}$ Yellow, Frog skin (Piel de Sapo) and Charentais are types of melon; ${ }^{3}$ Virulence based on the severity of symptoms in melon fruits (Melo et al., 2015). Numbers in parentheses are standard errors ( \pm SE); ${ }^{4}+$ slightly virulent (score 1.0 to 2.9 ), ++ moderately virulent (score 3.0 to 4.9 ) and +++ very virulent (score 5.0 to 6.0 ); ${ }^{5}$ Mean of four repetitions. Each value represents the mean of two independent experiments. For analysis purposes, the data were transformed into $R(x+1)$. Means followed by the same letter in the vertical direction do not differ significantly according to the Scott-Knott test ( $p<$ $0.05) ;{ }^{6}$ Unknown. Infected fruit collected at a commercial center in Recife, PE.

the $34 \mathrm{~A}$. citrulli strains from the Culture Collection of the Phytobacteriology Laboratory, four melon strains (Ac1, Ac1.5, Ac1.12 and AcR2) renamed as AAC201-21, AAC201-22, AAC201-23, and AAC201-24 (Walcott et al., 2004) and classified in Group I, were included to compare their pathogenic, phenotypic and genotypic profiles. The bacterial suspensions used in our experiments were adjusted to an $\mathrm{A}_{580}=0.25\left(3.4 \times 10^{7} \mathrm{CFU} \mathrm{mL} \mathrm{mL}^{-1}\right)$ using a spectrophotometer.

\section{Virulence assay}

Detached yellow type melon fruit, approximately 70-day old, were inoculated using the subepidermal injection method (Somodi et al., 1991). After washing with 
soap and water and drying, each fruit was marked with four parallel lines along its length. Bacteria were suspended in sterile water and diluted to $3.4 \times 10^{7} \mathrm{CFU}$ $\mathrm{mL}^{-1}$. One hundred microliters of bacterial suspension was then injected just under the rind surface, in the intercellular spaces, at three points on each line using a hypodermic syringe. Negative controls were fruits treated in a similar manner with sterile distilled water. The fruits were then incubated at ambient temperature $(25$ $\pm 2{ }^{\circ} \mathrm{C}$ ). The experiment was arranged in a completely randomized design with four replicates (fruits) per treatment (strain). The experiment was conducted twice. The fruits were evaluated eight days after inoculation for the severity of BFB symptoms (Melo et al., 2015) using a 1- to 6-grade scale, where: 1- no rind darkening, light pulp discoloration and no cavity formation in the pulp; 2- rind darkening, light pulp discoloration and no cavity formation in the pulp; 3- rind and pulp darkening and no cavity formation in the pulp; 4- no rind darkening, light pulp discoloration and cavity formation in the pulp; 5- rind darkening, light pulp discoloration and cavity formation in the pulp; and 6- rind and pulp darkening and cavity formation in the pulp.

\section{Substrate utilization profiles}

A. citrulli strains were cultivated in universal growth medium BUG for $24 \mathrm{~h}$ at $28{ }^{\circ} \mathrm{C}$ and suspensions were prepared in inoculation fluid A (Biolog) at a concentration of $1 \times 10^{8} \mathrm{CFU} \mathrm{mL}^{-1}$, determined using spectrophotometry. For each strain, $150 \mu \mathrm{L}$ of suspension was transferred to each well of a Biolog GN plate and the plates were incubated at $28{ }^{\circ} \mathrm{C}$ for $12 \mathrm{~h}$. Utilization of the 95 substrates, as indicated by a change in color, was visually evaluated and converted into binary data. The experiment was conducted twice.

\section{Extraction of DNA, PCR amplification and se- quencing}

Genomic DNA was extracted using the Multisource Genomic DNA Miniprep Kit following the manufacturer's instructions. DNA concentrations were estimated visually in agarose gel by comparing the band intensity using a 1-kb DNA ladder.

In this study, all strains were amplified using the WFB1 and WFB2 primers (Walcott and Gitaitis, 2000), which were used to confirm their identity. PCR was carried out in a Perkin Elmer thermal cycler. The program consisted of $1 \mathrm{~min}$ at $95^{\circ} \mathrm{C}$, followed by 30 cycles of 5 min at $95^{\circ} \mathrm{C}, 30 \mathrm{~s}$ at $65^{\circ} \mathrm{C}, 30 \mathrm{~s}$ at $72{ }^{\circ} \mathrm{C}$ and a final extension of $5 \mathrm{~min}$ at $72^{\circ} \mathrm{C}$. PCR products were separated using $2 \%$ agarose gel electrophoresis and visualized in photo documenter after staining.

The primers targeting the REP, ERIC and BOX sequences (Louws et al., 1994) were used for the rep-PCR reactions. The $15 \mu \mathrm{L}$ amplification reaction consisted of $1.5 \mu \mathrm{L}$ of $10 \mathrm{X}$ buffer $(500 \mathrm{mM} \mathrm{KCl}, 100 \mathrm{mM}$ Tris $\mathrm{HCl}$, $\mathrm{pH} 8.8$ at $\left.25{ }^{\circ} \mathrm{C}\right) ; 2.5 \mathrm{mM} \mathrm{MgCl}_{2} ; 10 \%$ DMSO; $0.4 \mathrm{mM}$ of each dNTP; $1 \mu \mathrm{M}$ of each primer (REP; ERIC or BOX-
PCR); 1 U of Taq DNA Polymerase; $2 \mu \mathrm{L}$ of DNA ( 20 ng); and ultrapure, sterilized water.

The samples were amplified in thermal cycler. For the REP primers, the PCR reaction tube was incubated in the thermal cycler at $95{ }^{\circ} \mathrm{C}$ for an initial warm-up period of $1 \mathrm{~min}$, followed by denaturation at $95{ }^{\circ} \mathrm{C}$ for $6 \mathrm{~min}, 35$ cycles of denaturation at $94{ }^{\circ} \mathrm{C}$ for $1 \mathrm{~min}$, annealing of primers at $40^{\circ} \mathrm{C}$ for $1 \mathrm{~min}$, and elongation at $65{ }^{\circ} \mathrm{C}$ for $5 \mathrm{~min}$. For the ERIC primers, initial denaturation occurred at $95^{\circ} \mathrm{C}$ for $7 \mathrm{~min}$, followed by 35 cycles of denaturation at $94^{\circ} \mathrm{C}$ for $1 \mathrm{~min}$, and $52^{\circ} \mathrm{C}$ for $1 \mathrm{~min}$, and ultimately $65^{\circ} \mathrm{C}$ for $8 \mathrm{~min}$. For the BOX primer, the samples were submitted to the following program: $95{ }^{\circ} \mathrm{C}$ for $7 \mathrm{~min}$, followed by 35 cycles of $94^{\circ} \mathrm{C}$ for $1 \mathrm{~min}, 55$ ${ }^{\circ} \mathrm{C}$ for $1 \mathrm{~min}$ and $72{ }^{\circ} \mathrm{C}$ for $8 \mathrm{~min}$. The reactions were completed by incubating the tubes at $65^{\circ} \mathrm{C}$ for $15 \mathrm{~min}$.

The amplified products were separated on $2 \%$ agarose gels using electrophoresis at $80 \mathrm{~V}$ for $2 \mathrm{~h}$ and $30 \mathrm{~min}$. After electrophoresis, the gel was stained as described above. We used the 1-Kb DNA ladder as the standard.

A subset of 15 strains, selected to represent the range in genetic diversity and virulence level, was used to amplify and sequence the $23 \mathrm{~S}$ rDNA region. The PCR amplification for this region was carried out using the primer pair 16F27 (5' GAAGTCGTAACAAGG $\left.3^{\prime}\right)$ and 16R1488 (5' CAAGGCATCCACC 3') (Lane, 1991). The PCR products were purified using the PCR Cleanup Kit following the manufacturer's instructions. DNA sequencing of the 23S rDNA region was performed using the Platform of Embrapa Genetic Resources \& Biotechnology (Brasília, Brazil).

\section{Phylogenetic analysis}

The quality assessment of the nucleotide sequences and the contig assembly were carried out using the Staden Package (Staden et al., 1998). Multiple sequence alignments of each gene were determined using ClustalW as implemented in MEGA v.5 (Tamura et al., 2011) and were manually adjusted to allow maximum sequence similarity.

Bayesian inference (BI) was used to reconstruct the phylogenetic trees using MrBayes v. 3.2.1 (Ronquist, 2012). The multiple sequence alignments and the analysis of the data set were run twice for $5 \times 10^{7}$ generations. Samples were collected from the posterior every 1,000 generations; the first $25 \%$ of the generations were discarded as burn-in.

Phylogenetic tree was constructed based on the fourteen strains of $A$. citrulli selected to represent the range in genetic diversity and virulence level. Sequences of Acidovorax species obtained from GenBank were included in the analyses. A. valerianellae Gardan et al. was used as the outgroup in this analysis (Table 2).

\section{Statistical analyses}

Because the data from the fruit virulence assay for the two experiments were reproduced without sig- 
Table 2 - Strains of Acidovorax studied with details of culture collection, host, origin and the GenBank accession numbers for the 23S rDNA region sequences.

\begin{tabular}{|c|c|c|c|c|}
\hline Species & Culture Accession $\mathrm{N}^{01}$ & Host & Origin & GenBank Accession $\mathrm{N}^{\circ}$ \\
\hline Acidovorax avenae & ICMP 3138 & Panicum miliaceum L. & Korea & GU339096 \\
\hline Acidovorax cattleyae & ICMP 2826 & Cattleya sp. & China & GU339094 \\
\hline Acidovorax citrulli & LGM 5376 & Citrullus lanatus & USA & JQ743876 \\
\hline A. citrulli & Aac1.31 & Cucumis melo & Brazil & KR871808 \\
\hline A. citrulli & Aac1.49 & Cucumis melo & Brazil & KR871806 \\
\hline A. citrulli & Aac1.72 & Cucumis melo & Brazil & KR871798 \\
\hline A. citrulli & Aac1.83 & Cucumis melo & Brazil & KR871801 \\
\hline A. citrulli & Aac5.1 & Cucumis melo & Brazil & KR871809 \\
\hline A. citrulli & Aac5.28 & Cucumis melo & Brazil & KR871799 \\
\hline A. citrulli & AacR3 & Cucumis melo & Brazil & KR871796 \\
\hline A. citrulli & AacMP1 & Cucumis melo & Brazil & KR871802 \\
\hline A. citrulli & AacMP2 & Cucumis melo & Brazil & KR871800 \\
\hline A. citrulli & Aac1213 & Cucumis melo & Brazil & KR871804 \\
\hline A. citrulli & IBSBF1214 & Citrullus lanatus & Brazil & KR871803 \\
\hline A. citrulli & IBSBF1521 & Citrullus lanatus & Brazil & KR871807 \\
\hline A. citrulli & IBSBF1627 & Citrullus lanatus & Brazil & KR871797 \\
\hline A. citrulli & IBSBF1851 & Citrullus lanatus & Brazil & KR871805 \\
\hline Acidovorax konjaci & ICMP 7733 & Amorphophallus rivieri & Japan & GU339095 \\
\hline Acidovorax valerianellae & KACC 16998 & Cucumis sativus & South Korea & KF931158 \\
\hline
\end{tabular}

IICMP, Culture Collection of the Plant Disease Division, New Zealand Department of Scientific and Industrial Research, Auckland, New Zealand; LMG, Culture Collection. Laboratorium voor Microbiologie, State University of Ghent, Ghent, Belgium; Aac- Culture Collection of the Phytobacteriology Laboratory of the Federal Rural University of Pernambuco, Recife, Brazil; IBSBF- Phytobacteria Culture Collection of the Biological Institute, São Paulo, Brazil; KACC - Korean Agricultural Culture Collection, National Institute of Agricultural Biotechnology, Korea.

nificant differences, they were analyzed jointly. The data were subjected to analysis of variance (ANOVA) as well as a means comparison by the Scott-Knott test $(p<0.05)$.

Data from the substrate utilization profiles were transformed into binary data and analyzed by the NTSYS (NTSYS-pc 2.0) program, using the Simple Matching coefficient and the UPGMA (Unweighted Pairwise Group Method Arithmetic Mean) method.

For rep-PCR analyses, the presence/absence of amplified fragments was converted into binary data $11=$ presence and $0=$ absence of fragments). The generated values for each strain (based on the differential migration of amplicons) were compared and their similarities were estimated using the Jaccard coefficient (Rohlf, 1994). The grouping analysis generated by UPGMA was represented by a dendrogram (NTSYS-pc 2.0) for the evaluation of strain variability.

\section{Results}

\section{Identification and virulence of the Acidovorax citrulli strains}

Genomic DNAs of the 34 strains was PCR-amplified using the primers WFB1 and WFB2, generating a band of approximately $360 \mathrm{bp}$.

Taking into consideration the severity of the BFB symptoms in melon assays, we observed three groups of strains, which were classified into three virulence levels, namely: slightly (1.0 to 2.9 ), moderately (3.0 to 4.9 ) and highly virulent (5.0 to 6.0) (Table 1). Most (60 \%) strains induced cavity formation in the pulp (scores 4 to
6) and were considered as moderately or highly virulent. Except for IBSBF1627 (moderately virulent), the other watermelon strains (Ac180, IBSBF1213, IBSBF1214 and IBSBF1851) were all slightly virulent on melon, and the ones from 'melão-pepino' were also slightly (AcMP1) or moderately (AcMP2) virulent on this host.

\section{Substrate utilization profiles}

Out of the 95 substrates included in the Biolog GN plates, $94 \%$ were utilized by at least one $A$. citrulli strain as a carbon source. None of the substrates were utilized by all strains. Only $\alpha$-cyclodextrin, D-galactonic acid lactone, hydroxy-L-proline, L-omithine, putrescine, and $\alpha$-D-glucose-1-phosphate were not utilized. The substrates most commonly used (listed in order of frequency) were: $\beta$-hydroxybutyric acid (98\%), L-aspartic acid (98 \%), L-glutamic acid (98 \%), L-asparagine (95\%), D-gluconic acid (93\%), L-arabinose (93\%), acetic acid (90\%), monomethyl succinate (90\%), bromo succinic acid (90\%), succinic acid (90\%), D-L-lactic acid (88\%), Tween-40 (88 \%), Tween-80 (88 \%), pyruvic acid methyl ester (80\%), 2-amino ethanol (75\%), $\alpha$-D-glucose (63 $\%)$, L-pyroglutamic acid (63\%), propionic acid (63\%), D-galactose (60 \%), L-proline (55\%), L-phenylalanine (53 $\%)$ and $\gamma$-hydroxybutyric acid (50\%). Considering all of the strains, $75 \%$ and $93 \%$ were negative for the utilization of L-leucine and $\alpha$-hydroxybutyric acid, respectively, whereas $75 \%$ were positive for 2-aminoethanol.

Analysis of the substrate utilization profiles demonstrated low variability between the strains at a $65 \%$ similarity level, with the formation of one group (Figure 1). 


\section{PCR analysis}

PCR amplification of DNA from the $A$. citrulli strains using the primers REP, ERIC and BOX (Figure 2) created multiple amplicons of different sizes. The use of the REP1R-I and REP2-1 primers generated 18 distinct bands ranging in size from 150 to $6000 \mathrm{bp}$. At the $65 \%$ similarity level, three groups were resolved: group 1 was represented by IBSBF1225, group 2 by Ac5.3 and group 3 by the remaining strains (data not presented).

Amplification using the ERIC primers (ERIC1R and ERIC2) generated 14 bands ranging from $280 \mathrm{bp}$ to $5000 \mathrm{bp}$, whereas amplification using the BOX1A primer generated 15 bands ranging from $300 \mathrm{bp}$ to $5000 \mathrm{bp}$. The ERIC and BOX primers generated a single group at the $65 \%$ similarity level (data not presented).

In the joint analysis of the rep-PCR data at the 65 $\%$ similarity level, a single group was formed (Figure 3). None of the rep-PCR primers resolved the strains in relation to the host of origin, which suggests limited genetic variability.

The grouping of the $A$. citrulli strains based on rep-PCR analysis confirmed the low genetic variability observed in the grouping based on the individual REP, ERIC and BOX-PCR data sets and that based on the substrate utilization profile analyses. The data set suggests that the studied strains belong to a single group, previously described as Group I in the United States by Walcott et al. (2000, 2004).

\section{Phylogenetic analysis}

The 23S rDNA sequence of the selected $A$. citrulli strains had a high degree of similarity with that of the type species of $A$. citrulli. The $23 \mathrm{~S}$ rDNA gene sequences of $A$. citrulli ranged from 605 to 784 bp. Bayesian inference was performed on the data sets composed of 464 characters after alignment. The resulting data set contained one well-supported clade, into which the strains with the type species with high posterior probability support were clustered (Figure 4).

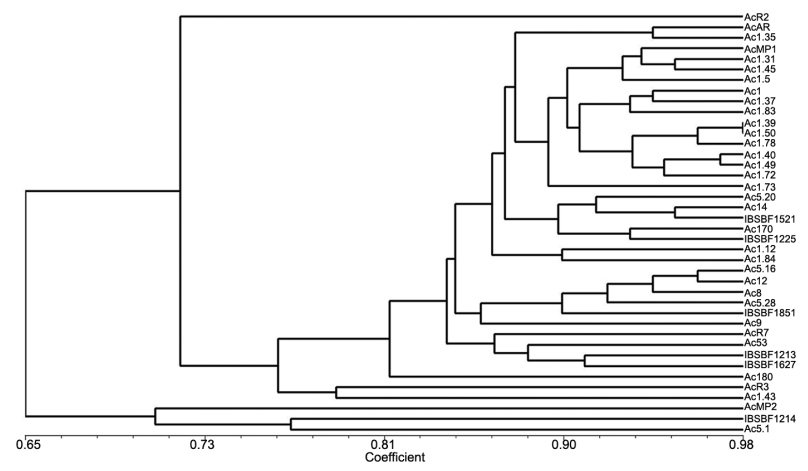

Figure 1 - Analysis of Acidovorax citrulli strain grouping based on the utilization of 95 carbon sources (Biolog GN System). The dendrogram is based on the Simple Matching Coefficient and UPGMA (Unweighted Pairwise Group Method Arithmetic Mean).

\section{Discussion}

The analyzed strains were confirmed as $A$. citrulli because when these strains were amplified using the WFB1 and WFB2 primers, a 360-bp amplicon was generated. The WFB1 and WFB2 primer specificity is contestable because DNA from A. avenae Williams et al., A. konjaci (Goto) Willems K. Koch, A. cattleyae (Pavarino) Schaad et al., Acidovorax sp. of Calathea sp. and Comamonas testosteroni (Mar-
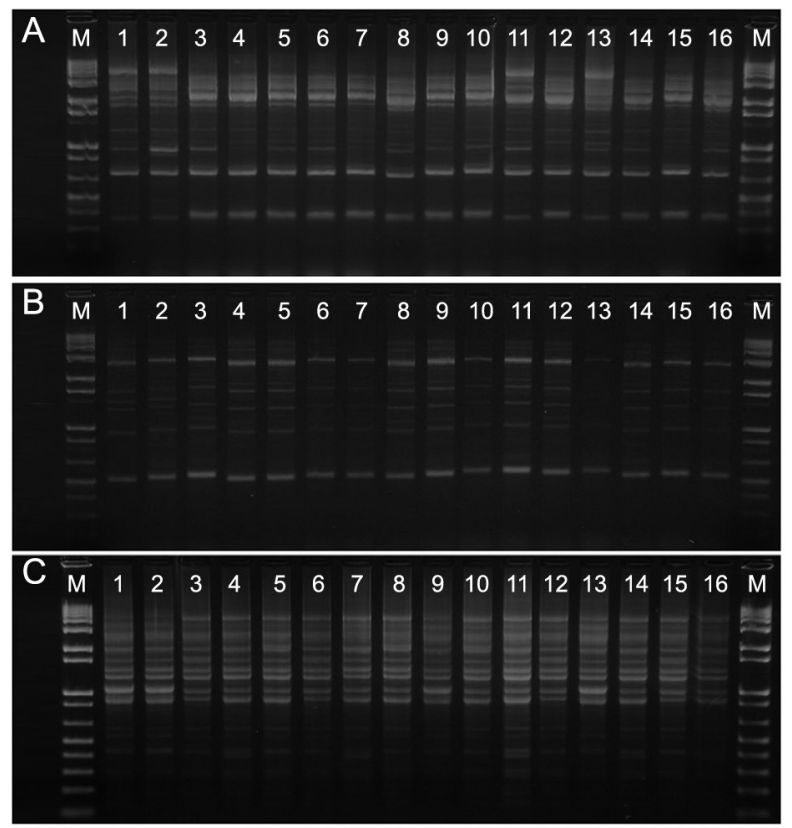

Figure 2 - Representative genetic fingerprinting of Acidovorax citrulli strains obtained using REP- (A), ERIC- (B) and BOX-PCR (C). Lane M: molecular marker (1-kb ladder). Lane 1 to 16: 1 - AacR3; 2 Aac5.20; 3 - Aac1.45; 4 - Aac1.5; 5 - AacAR; 6 - Aac9; 7 - Aac1.84; 8 - AacR5.28; 9 - Aac14; 10 - Aac180; 11 - Aac12; 12 - Aac1.78; 13 - IBSBF1627; 14 - Aac1.35; 15 - Aac1.49; and 16 - Aac1.37.

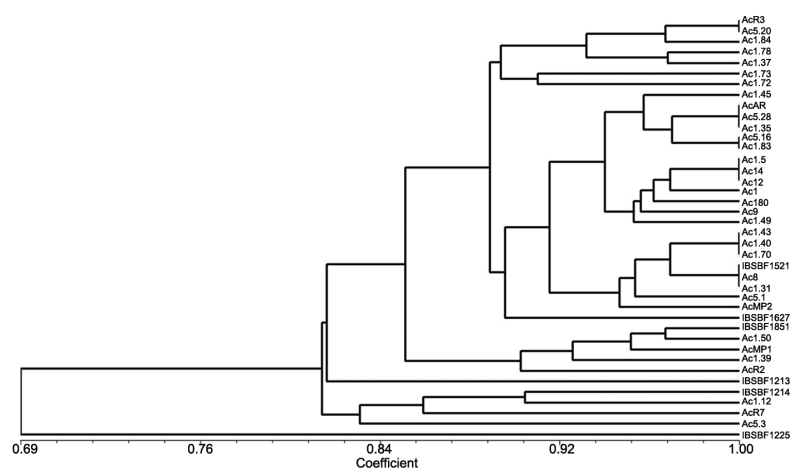

Figure 3 - Analysis of Acidovorax citrulli strain grouping based on the fingerprinting profiles generated by the amplification of the REP, ERIC and BOX elements. Distance matrix data were generated using the Jaccard similarity coefficient, and the dendrogram was constructed using the UPGMA algorithm grouping method (Unweighted Pairwise Group Method Arithmetic Mean). 


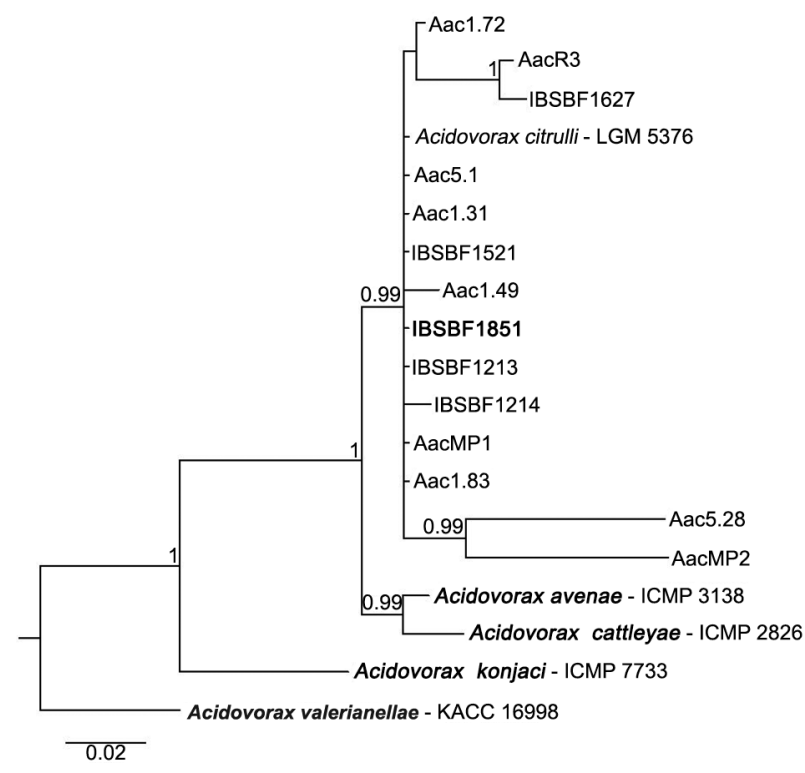

Figure 4 - A Bayesian inference phylogenetic tree of 15 Acidovorax citrulli strains using the $23 \mathrm{~S}$ rDNA gene sequence. The tree shows the phylogenetic relationships between Acidovorax species isolated from melon and watermelon. Bayesian posterior probability values $\geq 0.6$ are shown in each node. Type sequences are emphasized in bold font. Culture accession numbers are listed. Acidovorax valerianellae was used as an outgroup. The scale bar indicates the number of expected changes per site.

cus and Talalay) Tamaoka et al. was also amplified by these primers (Walcott and Gitaitis, 2000). However, the use of these primers is valid because the above-mentioned bacteria do not cause BFB symptoms in melon plants. Additionally, the phylogenetic analysis showed that all 15 strains included in this study belong to the species $A$. citrulli, with high posterior probability support.

Cluster analysis based on the severity of BFB in melon fruits showed the formation of three virulence groups, indicating variability between the strains. Our results agree with those obtained in other studies (Silveira et al., 2003; Oliveira et al., 2007). Although hostrelated groups were not observed, the watermelon and 'melão-pepino' strains exhibited only low or moderate virulence on melon. Additionally, from the four group-I strains described by Walcott et al. (2004) that were studied here, two were classified as highly virulent, while two were classified as slightly virulent, indicating that all strains analyzed belong to a single group.

Differences in host susceptibility to BFB have been reported. The watermelon cv. Crimson Sweet was more susceptible than the cantaloupe melon cv. Athena when both were inoculated with 10 strains of $A$. citrulli representing groups I and II (Walcott et al., 2004). Moreover, the pathogen virulence was generally demonstrated to be host specific (Burdman et al., 2005; Oliveira et al., 2007), indicating that melon strains were more virulent to melon than to watermelon, and vice versa.
A majority of the $A$. citrulli strains induced cavity formation in melon fruit pulp, which is a characteristic of moderate or high virulence. With the exception of viroids and viruses, pathogens are known to remove nutrients from the vegetal cell protoplasm. Most phytobacteria disintegrate the vegetal tissue through the action of toxins and/or enzymes that liberate cellular fluids into the intercellular space to be used by the pathogen after enzymatic degradation (Kado, 2010). Until now, no study has demonstrated the production of enzymes and/ or toxins with this function in A. citrulli; however, it is likely that the production of some compound responsible for cavity formation exists. This compound can be considered a virulence factor because some strains are pathogenic but do not form cavities. Amylase, protease, pectinase and cellulase activities were mentioned as $A$. citrulli virulence factors (Schaad et al., 1978; Walcott et al., 2004; Burdman et al., 2005), but the role of such enzymes in $A$. citrulli virulence on fruit tissues remains to be determined (Burdman et al., 2005). In contrast, the production of amylolytic, proteolytic, pectolytic and cellulolytic enzymes was not detected in $41 \mathrm{~A}$. citrulli strains, even if lipolytic activity was detected (Oliveira et al., 2007).

The substrate utilization profile analysis revealed that the majority of the tested compounds were used by $A$. citrulli strains as a carbon source. Among the compounds that were most commonly used in this study, Tween-80, monomethyl succinate, acetic acid, $\beta$-hydroxybutyric acid, D-L-lactic acid, succinic acid, bromo succinic acid, L-asparagine, L-aspartic acid and L-pyroglutamic acid were also mentioned by Walcott et al. (2004).

The majority of the studied strains were obtained from melon, and a high percentage $(88 \%)$ of them were negative for the utilization of L-leucine and $\alpha$-hydroxybutyric acid and positive for 2-amino ethanol, which is in agreement with previous studies (O'Brien and Martin, 1999; Walcott et al., 2004; Burdman et al., 2005). Nevertheless, Oliveira et al. (2007) found that several of these strains used L-leucine, including Ac1, Ac1.5, Ac1.12 and AcR2. These melon strains, respectively named by Walcott et al. (2004) as AAC201-21, AAC201-23, AAC201-22 and AAC201-24, did not use L-leucine. Oliveira et al. (2007) attributed this discrepancy to the method used. Therefore, the utilization of L-leucine to distinguish watermelon strains (positive for L-leucine) from other cucurbitaceous strains (negative for L-leucine), among other tests (O’Brien and Martin, 1999; Burdman et al., 2005), is not recommended given that the results are not valid for $100 \%$ of the strains and can vary according to the method employed, or even when the same method is used. This last fact is exemplified by the Ac1 strain, which was L-leucine-negative in the Biolog tests carried out by Walcott et al. (2004), but positive in the present study. Therefore, we agree with Burdman et al. (2005) who noted there is a problem in the Biolog database, which indicated that none of the $A$. citrulli strains would utilize L-leucine or use D-glucose. 
The substrate utilization profile analysis indicated low variability, i.e., one group without a host relationship. Considering that four of the analyzed melon strains were classified by Walcott et al. (2004) as part of Group I and that these same strains were grouped with the other strains in this study, we suggest that the strains utilized here correspond to the Walcott Group I.

PCR amplification with the REP, ERIC and BOX primers enabled the analysis of variability among the $A$. citrulli strains studied, which exhibited variable numbers and sizes of bands. In particular, the REP primer generated the greatest number of amplicons. Similar results were obtained using this technique to characterize $12 \mathrm{~A}$. citrulli strains, six of which were derived from watermelon and six from melon, from Israeli plantations (Burdman et al., 2005). In the rep-PCR data analysis, the strains formed a single group at the $65 \%$ similarity level, indicating low variability.

Using BOX-PCR, Walcott et al. (2004) reported two distinct groups at the $65 \%$ similarity level among 64 A. citrulli strains collected from cucurbitaceous plants in the United States, China, Taiwan, Thailand, Canada, Australia, Brazil and Israel. Group I contained 56 $\%$ of the strains, derived from cucurbitaceous plants other than watermelon and the ATCC29625 strain type (IBSBF1851), and Group II contained $44 \%$ of the strains, all derived from watermelon. Additionally, BOX-, REPand ERIC-PCR resolved the melon- and watermelonderived strains into two different groups, and the BOX primer was more efficient in separating the strains (Burdman et al., 2005). Melo et al. (2014) also used BOXPCR and found the occurrence of only one group at the $65 \%$ similarity level among 22 A. citrulli strains collected from cucurbitaceous plants in three different Brazilian states (Rio Grande do Norte, Rio Grande do Sul and Minas Gerais), indicating the presence of only one group in Brazil. Therefore, using the BOX1A primers as a parameter, we found that all strains formed a single cluster at the $65 \%$ similarity level and that the two groups occurred only at the $79 \%$ similarity level, indicating low variability among the Brazilian strains. Taken together, these results clearly indicate that all strains analyzed here belong to group I described by Walcott et al. (2004).

Due to the absence of additional strains isolated from watermelon from Brazil as well as other group-II strains sensu Walcott et al. (2004), it is not possible to resolve the strains into the two groups based on nutritional markers and rep-PCR. In Brazil, over the last decade, BFB has had a severe economic impact, particularly on melon (Carvalho et al., 2013). Given that $70 \%$ of the studied strains originated from the same municipality/ state, i.e., Baraúna-RN, it is possible that $A$. citrulli were introduced into the region through the importation of infected seeds, as proposed by Assis et al. (1999). Additionally, it is likely that melon strains that originated from these first outbreaks later spread to watermelon plantations. This would explain why severe BFB has not routinely caused outbreaks in watermelon in Brazil.
In conclusion, based on the markers used, the Brazilian $A$. citrulli strains studied belong to a single group that corresponds to the Walcott Group I (Walcott et al., 2004). Given that strains of the Walcott Group II are possibly not present in northeastern Brazil, it is very important that such strains are not introduced because they are more virulent to watermelon than to other cucurbit plants. Furthermore, BFB is not an economic problem for this crop in Brazil. In addition, the low variability detected among the tested Brazilian A. citrulli strains is an important factor to be considered in the improvement, introduction and production of resistant cultivars for the control of BFB in melon.

\section{Acknowledgments}

We thank the Coordination for the Improvement of Higher Level Personnel (CAPES) for a scholarship to K.M.M. Silva and the Brazilian National Council for Scientific and Technological Development (CNPq) for the research fellowships awarded to R.L.R. Mariano and E.B. Souza (Proc. 302078/2008-8).

\section{References}

Assis, S.M.P.; Mariano, R.L.R.; Silva-Hanlin, D.M.W.; Duarte, V. 1999. Bacterial fruit blotch caused by Acidovorax avenae subsp. citrulli in melon in the state of Rio Grande do Norte, Brazil. Fitopatologia Brasileira 24: 191 (in Portuguese, with abstract in English).

Burdman, S.; Walcott, R. 2012. Acidovorax citrulli: generating basic and applied knowledge to tackle a global threat to the cucurbit industry. Molecular Plant Pathology 13: 805-815.

Burdman, S.; Kots, N.; Kritzman, G.; Kopelowitz, J. 2005. Molecular, physiological, and host-range characterization of Acidovorax avenae subsp. citrulli isolates from watermelon and melon in Israel. Plant Disease 89: 1339-1347.

Carvalho, F.C.Q.; Santos, L.A.; Dias, R.C.S.; Mariano, R.L.R.; Souza, E.B. 2013. Selection of watermelon genotypes for resistance to bacterial fruit blotch. Euphytica 190: 169-180.

European and Mediterranean Plant Protection Organization [EPPO]. 2010. Acidovorax citrulli: bacterial fruit blotch of cucurbits. Available at: http://www.eppo.int/QUARANTINE/Alert_List/ bacteria/Acidovorax_citrulli.htm [Accessed Feb. 4, 2015].

Kado, C.I. 2010. Molecular mechanisms of virulence and pathogenesis. p. 229-276. In: Kado, C.I., ed. Plant bacteriology. The American Phytopathological Society, St. Paul, MN, USA.

Lane, D. 1991. 16S/23S sequencing. p. 115-175. In: Stackebrandt, E.G.; Goodfellow, M., ed. Nucleic acid techniques in bacterial systematics. John Wiley, Chichester, England.

Louws, F.J.; Fulbright, D.W.; Stephens, C.T.; Bruijn, F.J. 1994. Specific genomic fingerprints of phytopathogenic Xanthomonas and Pseudomonas cultivars and strains generated with repetitive sequences and PCR. Applied and Environmental Microbiology 60: 2286-2295.

Melo, L.A.; Tebaldi, N.D.; Mehta, A.; Marques, A.S.A. 2014 Comparing Acidovorax citrulli strains from melon and watermelon: phenotypic characteristics, pathogenicity and genetic diversity. Tropical Plant Pathology 39: 154-162. 
Melo, E.A.; Mariano, R.L.R.; Laranjeira, D.; Santos, L.A.; Gusmão, L.O.; Souza, E.B. 2015. Efficacy of yeast in the biocontrol of bacterial fruit blotch in melon plants. Tropical Plant Pathology 40: 56-64.

Oliveira, J.C.; Silveira, E.B.; Mariano, R.L.R.; Cardoso, E.; Viana, I. 2007. Characterization of strains of Acidovorax avenae subsp. citrulli. Fitopatologia Brasileira 32: 480-487 (in Portuguese, with abstract in English).

O'Brien, R.G.; Martin, H.L. 1999. Bacterial blotch of melons caused by strains of Acidovorax avenae subsp. citrulli. Australian Journal of Experimental Agriculture 39: 479-485.

Rohlf, F.J. 1994. NTSYS-pc: Numerical Taxonomy and Multivariate Analysis System: Version 2.1 User Guide. State University of New York, NY, USA.

Ronquist, F.; Teslenko, M.; Mark, P. van der; Ayres, D.L.; Darling, A.; Höhna, S.; Larget, B.; Liu, L.; Suchard, M.A.; Huelsenbeck, J.P. 2012. MrBayes v. 3.2: efficient Bayesian phylogenetic inference and model choice across a large model space. Systematic Biology 61: 539-542.

Schaad, N.W.; Sowell, G.; Goth, R.W.; Colwell, R.R.; Webb, R.E. 1978. Pseudomonas pseudoalcaligenes subsp. citrulli. International Journal of Systematic Bacteriology 28: 117-125.

Silveira, E.B.; Mariano, R.L.R.; Michereff, S.J. 2003. Variability of strains of Acidovorax avenae subsp. citrulli from melon produced in the Rio Grande do Norte state, Brazil. Summa Phytopathologica 29: 255-261 (in Portuguese, with abstract in English).
Somodi, G.C.; Jones, J.B.; Hopkins, D.L.; Stall, R.E.; Kucharek, T.A.; Hodge, N.C.; Watterson, J.C. 1991. Occurrence of bacterial watermelon fruit blotch in Florida. Plant Disease 75: 1053-1056.

Staden, R.; Beal, K.F.; Bonfield, J.K. 1998. The Staden package. p. 115-130. In: Misener, S; Krawetz, S.A., eds. Bioinformatics methods and protocols. Humana, New York, NY, USA. p.115130.

Tamura, K.; Peterson, D.; Peterson, N.; Stecher, G.; Nei, M. 2011. MEGA5: molecular evolutionary genetics analysis using maximum likelihood, evolutionary distance, and maximum parsimony methods. Molecular Biology and Evolution 28: 2731-2739.

Walcott, R.R.; Fessehaie, A.; Castro, A.C. 2004. Differences in pathogenicity between two genetically distinct groups of Acidovorax avenae subsp. citrulli on cucurbit hozsta. Journal of Phytopathology 152: 277-285.

Walcott, R.R.; Gitaitis, R.D. 2000. Detection of Acidovorax avenae subsp. citrulli in watermelon seed using immunomagnetic separation and polymerase reaction. Plant Disease 84: 470-474.

Walcott, R.R.; Langston, D.B.; Sanders, F.H.; Gitaitis, R.D. 2000. Investigating intraspecific variation of Acidovorax avenae subsp. citrulli using DNA fingerprinting and whole cell fatty acid analysis. Phytopathology 9: 191-196. 